\title{
高分子量第四アンモニウム塩による塩酸 溶液からのルテニウム（III）の抽出*
}

\author{
渡辺 漛 $^{1}$ 楠

\section{Extraction of Ruthenium (III) from Hydrochloric Acid Solutions by High Molecular-Weight Quaternary Ammonium Compound} \\ by Hiroshi WATANABE ${ }^{1}$ and Yasushi KUSUNOKI ${ }^{1}$ \\ 1. Faculty of Engineering, Shizuoka University, Johoku, Hamamatsu 432
}

靖 ${ }^{2}$

\begin{abstract}
The extraction of ruthenium (III) from hydrochloric acid solutions has been investigated by using a trioctylmethylammonium chloride $\left(\mathrm{R}_{3} \mathrm{R}^{\prime} \mathrm{NCl}\right)$ in various diluents.

The extraction isotherm shows a minimum value at $1.5-2 \mathrm{~mol} \mathrm{dm}^{-3}$ in initial aqueous hydrochloric acid solution. Hence, it is suggested that the extraction species varies in low acidity ( $\leqq 1.5 \mathrm{~mol} \mathrm{dm}^{-3}$ $\mathrm{HCl})$ and higher acidity $\left(\geqq 1.5 \mathrm{~mol} \mathrm{dm}^{-3}\right)$. Stoichiometric composition of the complexes formed in the organic phase deduced to be $\mathrm{R}_{3} \mathrm{R}^{\prime} \mathrm{NRu}(\mathrm{OH})_{2} \mathrm{Cl}_{2} \cdot 2 \mathrm{H}_{2} \mathrm{O}$ at low acidity and $\mathrm{R}_{3} \mathrm{R}^{\prime} \mathrm{NRuOCl}{ }_{2} \cdot \mathrm{H}_{2} \mathrm{O}$ at higher acidity. These results are also confirmed by infrared spectral measurement of the extracts.

In the examination of diluents effects, chlorobenzene and o-dichlorobenzene most promoted the extraction of $\mathrm{Ru}(\mathrm{III})$ at low and higher acidities, respectively.

The distribution ratios increase with increasing temperature in the both acidities.

KEY WORDS : Extraction of ruthenium(III), Hydrochloric acid, Trioctylmethylammonium chloride, Diluent effect, Stoichiometric composition.
\end{abstract}

\section{1. 緒}

近年，ルテニウムは触媒および電子材料として使用され注目され ている。そしてその需要は年々増加しており, 使用済み材料からの ルテニウムの回収が強く要望されている。現在ルテニウムの精錬に は溶媒抽出技術が取り入れられており, 使用済み材料からのルテニ ウムの回収にもこの技術の利用が期待できる。

白金属金属の溶媒抽出については種々報告がなされており，その 総説についてまとめられている1)。しかしルテニウムは多くの酸化 状態を取り, 様々の化学的挙動を示すため ${ }^{2)}$, その分配について調 べられているのみで ${ }^{3)}$, 生成する錯体の組成などについての検討は ほとんどなされていない。

著者らは既に溶媒抽出で生成する第四アンモニウム塩のルテニウ ム(III)クロ口錯体とその熱分解について一部報告したが ${ }^{4)}$, 本研究 では, ルテニウム回収のための基礎的な資料を得る目的で, 塩化卜 リオクチルメチルアンモニウムによる塩酸溶液からのルテニウム (III)の抽出について研究し, さらに希釈剂の抽出に及ぼす効果につ いても調べた ${ }^{5) 6) 。}$

* 1993年 7 月30日受付 10 月27日受理

1. 正会員 工博 静岡大学助教授 工学部応用化学科

2. 静岡大学 工学部応用化学科 (現 INAX(俰))

キーワード: ルテニゥム(III)の抽出, 塩酸, 塩化トリオクチルメチルアンモ 二ウム, 希釈剂効果, 化学量論的組成

\section{2. 実 験 方 法}

\section{$2 \cdot 1$ 試薬}

塩化トリオクチルメチルアンモニウム (広栄化学, $\mathrm{R}_{3} \mathrm{R}{ }^{\prime} \mathrm{NCl}: \mathrm{T}$ OMAC) は精製せず各種有機溶媒で目的濃度に希釈し, 予備平衡 を行わずに使用した。ルテニウム (III) 溶液は三塩化ルテニウム水和 物（エヌ・イー ケムキャット, $\mathrm{RuCl}_{3} \cdot n \mathrm{H}_{2} \mathrm{O} ; n=2.5-3.5$ )を 2 $\mathrm{mol} \mathrm{dm}{ }^{-3}$ 塩酸に溶解し, 化学種を安定させるために 50 時間以上室 温で放置した溶液を原液とした。実験には原液を塩酸とイオン交換 水で目的の酸性度と金属濃度 (連続変化法の実験を除き $0.001 \mathrm{~mol}$ $\left.\mathrm{dm}^{-3}\right)$ に調整した。その他の試薬はすべて特級のものを使用した。

\section{2 - 2 抽出操作}

抽出は有機溶媒（希釈剤効果を調べるとき以外はすべてベンゼン を使用した)で希釈したTOMAC溶液と所定の金属溶液の各等量 $\left(10 \mathrm{~cm}^{3}\right)$ を共栓付き遠心沈殿管 $\left(50 \mathrm{~cm}^{3}\right)$ に採取し,340 rpm の振晹 機で完全に平衡になるまで振り混ぜた後, 両相を遠心分離した。抽 出後の水相中に含まれる金属濃度を原子吸光分光分析により定量し た。そして次式より分配比 $(D)$ を求めた。

$$
D=\left([\mathrm{Ru}]_{\text {init aq }}-[\mathrm{Ru}]_{\mathrm{aq}}\right) /[\mathrm{Ru}]_{\mathrm{aq}}
$$

$[R u]_{\text {init aq }}$ おび $[R u]_{\text {aq }}$ はそれぞれ水相のルテニウム初濃度およ び抽出後のルテニウム濃度を表す。抽出温度は温度効果の検討の場

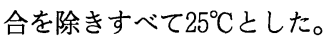




\section{$2 \cdot 3$ 分析および測定}

（1）ルテニウムの定量 水相のルテニウム溶液を試料とし，日 本 Jarrel-Ash 製 AA-782 型原子吸光分光分析装置で決定した。

（2）塩化物イオンおよび水分含有量の定量 有機相中の塩化物 イオン濃度は試料を約10倍量のアセトンで可溶化した後, ニトロベ ンゼンを適当量加えVolhard 法で測定した。抽出後の有機相中に 含まれる水分含有量は Karl-Fisher 滴定により調べた。

（3） 赤外吸収スペクトル測定 赤外吸収スペクトルはルテニウ ムを完全に飽和するまで負荷した有機相を減圧下（ $\leqq 60^{\circ} \mathrm{C} / 1$ $\mathrm{mmHg}$ ）で希釈剂を留去し，得られた抽出物をペースト法により， 日本分光製自記回折格子型赤外分光光度計 IR-Al および IR-F 型 を使用し，それぞれ波数範囲 $4,000-650 \mathrm{~cm}^{-1}$ および $700-200 \mathrm{~cm}^{-1}$ の測定を行った。セルはKRS-5またはポリエチレンフィルムを使 用した。

\section{3．実験結果および考察}

\section{$3 \cdot 1$ 抽出平衡時間}

ベンゼン希釈の $0.01 \mathrm{~mol} \mathrm{dm}^{-3}$ TOMACにより $0.5,1,2$ およ び $5 \mathrm{~mol} \mathrm{dm}$ 塩酸溶液からの $0.001 \mathrm{~mol} \mathrm{dm}{ }^{-3}$ ルテニウムの抽出を 行い抽出平衡時間を調べた。その結果をFig. 1 に示す。平衡に達 する時間は水相の塩酸初濃度が増加するに従って短くなり, 0.5 $\mathrm{mol} \mathrm{dm}{ }^{-3}$ 塩酸では約120分必要なのに対して $5 \mathrm{~mol} \mathrm{dm}^{-3}$ 塩酸では 40分程度であった。特に, この時間は $2 \mathrm{~mol} \mathrm{dm}^{-3}$ 塩酸を境に大き

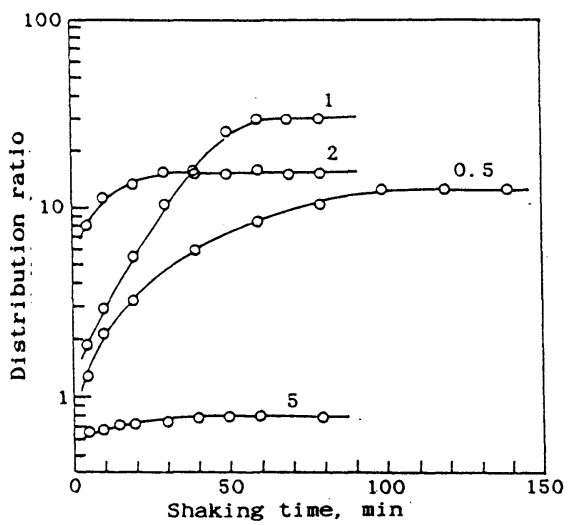

Numerals on curves are initial aqueous hydrochloric acid concentration, $\mathrm{mol} \mathrm{dm}{ }^{-3} ;$ Benzene diluent; [TOMAC] $=0.01$ $\mathrm{mol} \mathrm{dm}{ }^{-3} ;[\mathrm{Ru}(\mathrm{III})]=0.001 \mathrm{~mol} \mathrm{dm}{ }^{-3} ; 25^{\circ} \mathrm{C}$

Fig. 1 Extraction rate for the extraction of ruthenium(III).

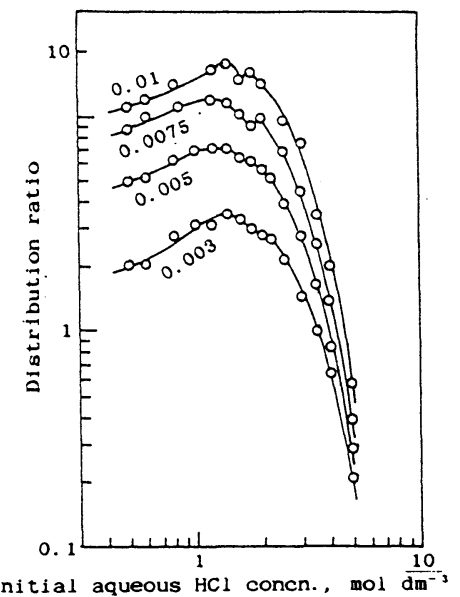

Numerals on curves are initial TOMAC concentration, mol $\mathrm{dm}^{-3}$; Benzene diluent $[\mathrm{Ru}(\mathrm{III})]=0.001 \mathrm{~mol} \mathrm{dm}^{-3} ; 25^{\circ} \mathrm{C}$

Fig. 2 Extraction isotherms of ruthenium ( III) from hydrochloric acid solutions.
く変化しており,この酸濃度付近で抽出化学種が異なる可能性を示 唆している。それ故以降の実験では, すべての塩酸領域で完全に平 衡に到達させるために抽出時間を180分に設定した。

\section{$3 \cdot 2$ 分配平衡}

ベンゼン希釈のTOMACにより水相の塩酸濃度を変化して0.001 $\mathrm{mol} \mathrm{dm}{ }^{-3}$ 塩化ルテニウムの抽出を行った結果をFig. 2 に示す。ル テニゥムの分配比は水相の塩酸初濃度の増加に伴って増大し, 1.5 $\mathrm{mol} \mathrm{dm}{ }^{-3}$ 付近で極大, そして $1.5-2 \mathrm{~mol} \mathrm{dm}^{-3}$ の間に極小值を示

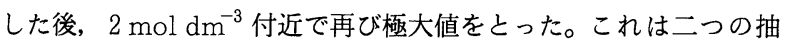
出曲線が重なって見掛け上このような形状になったと考えられる。 それ故この酸濃度付近を境にして, 塩酸濃度の低い低酸側（ $\leqq 1.5$ $\left.\mathrm{mol} \mathrm{dm}{ }^{-3} \mathrm{HCl}\right)$ と高い高酸側（ $\geqq 1.5 \mathrm{~mol} \mathrm{dm}^{-3} \mathrm{HCl}$ ) では抽出さ れるルテニウム化学種が異なると予想され，このこと はFig. 1 の結果と対応している。また, 塩化物イオンの抽出 に及ぼす影響を調べるために, 塩酸の大部分を塩化リチウムで置 き換えた溶液 $\left(0.5 \mathrm{~mol} \mathrm{dm}{ }^{-3} \mathrm{HCl}+\mathrm{Xmol} \mathrm{dm}{ }^{-3} \mathrm{LiCl}\right)$ から 0.001 $\mathrm{mol} \mathrm{dm^{-3 }}$ 塩化ルテニウムを抽出した結果 (Fig. 3), その分配 比は塩酸のみの溶液からの抽出とは異なり, 塩化物イオンの濃度 の增加に従い初めは減少するが, 水相の塩化物イオン初濃度 2 $\mathrm{mol} \mathrm{dm}{ }^{-3}$ 付近から増加し, $3-4 \mathrm{~mol} \mathrm{dm}^{-3}$ 付近で最大となった。 したがって低酸側ではプロトンそして高酸側では塩化物イオンが関 与して，抽出を促進することは明らかである。これらの現象はいず れもTOMAC濃度を変化してああまり左右されない。

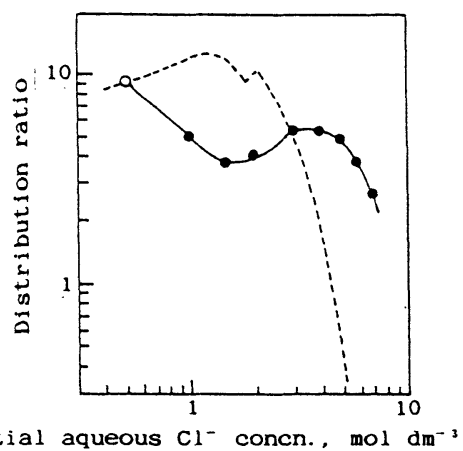

Dotted line represents the extracion curve from hydrochloric acid solutions alone, ; Benzene diluent; [TOMAC] $=0.0075$ $\mathrm{mol} \mathrm{dm}{ }^{-3} ;[\mathrm{Ru}($ III $)]=0.001 \mathrm{~mol} \mathrm{dm}^{-3} ; 25^{\circ} \mathrm{C}$

Fig. 3 Extraction isotherm of ruthenium ( III ) from hydrochloric acid solutions containing lithium chloride.

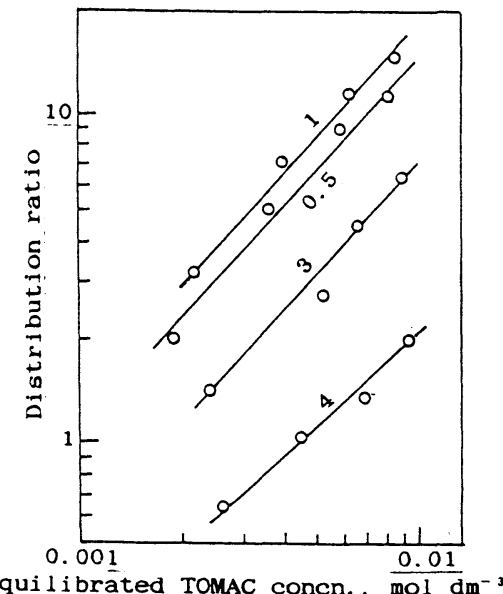

Numerals on lines are intial aqueous hydrochloric acid con-centration, mol dm${ }^{-3}$; Benzene diluent; $[\mathrm{Ru}(\mathrm{III})]=0.001 \mathrm{~mol} \mathrm{dm}^{-3} ; 25^{\circ} \mathrm{C}$

Fig. 4 Log-log plots of the distribution ratio vs. equilibrated TOMAC concentration. 


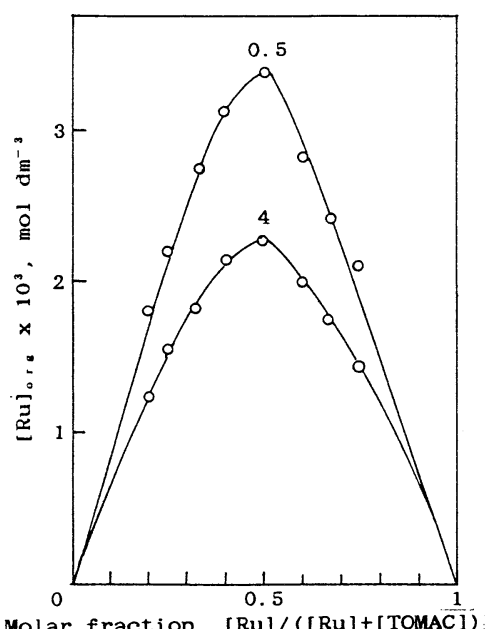

Molar fraction, [Ru]/([Ru]+[TOMAC])

Numerals on curves are initial aqueous hydrochloric acid concentration, mol dm ${ }^{-3}$; Benzene diluent; $[\mathrm{Ru}(\mathrm{III})]+$ [TOMAC] $=0.01 \mathrm{~mol} \mathrm{dm} \mathrm{dm}^{-3} ; 25^{\circ} \mathrm{C}$

Fig. 5 Experimental results of continuous variation method.

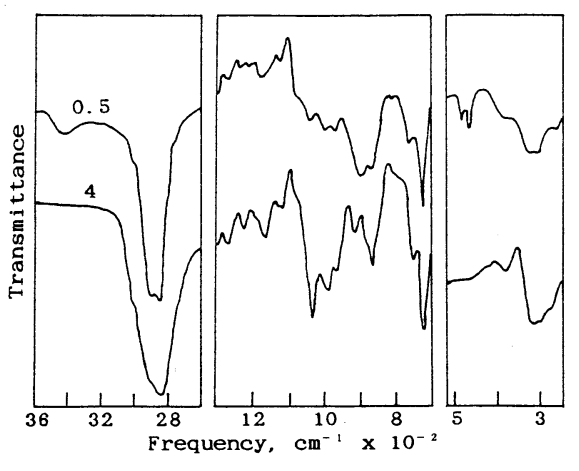

Numerals on curves are initial aqueous hydrochloric acid concentration, mol dm${ }^{-3}$

Fig. 6 Infrared spectra of the extracts with TOMAC.

\section{$3 \cdot 3$ 抽出錯体の組成}

まずTOMACとルテニウムの関係を知るために, ベンゼン希釈の TOMAC濃度を0.03-0.01 mol dm${ }^{-3}$ と变化し, 抽出を行った結果 をFig. 4 に示す。その結果, 分配比の対数と平衡後のTOMAC濃 度の対数との間にはほぼ直線関係が成立し, その傾きはすべての塩

Table 1 Composition of the extracted complexes formed by ultimate loading.

\begin{tabular}{|c|c|c|c|c|}
\hline \multirow{2}{*}{$\begin{array}{l}\text { InIt } \mid \text { al aqueous } \\
\mathrm{HCl} \text { concn., } \\
\text { mol } \mathrm{dm}^{-3}\end{array}$} & \multicolumn{3}{|c|}{ Molar rat 10} & \multirow{2}{*}{$\begin{array}{c}\text { Probable } \\
\text { stolchlometry }\end{array}$} \\
\hline & {$[\mathrm{Ru}]$} & / $\left[R_{3} R^{\prime} N\right]$ & $/[\mathrm{Cl}] /\left[\mathrm{H}_{2} \mathrm{O}\right]$ & \\
\hline 0.5 & 1 & $: \quad 1.04$ & $: 1.99: 2.15$ & $\mathrm{R}_{3} \mathrm{R}^{\prime} \mathrm{NRu}(\mathrm{OH})_{2} \mathrm{Cl}_{2} \cdot 2 \mathrm{H}_{2} \mathrm{O}$ \\
\hline 4 & 1 & $: \quad 1.07$ & $: 1.86: 0.95$ & $\mathrm{R}_{3} \mathrm{R}^{\prime} \mathrm{NRuOCl} \mathrm{C}_{2} \cdot \mathrm{H}_{2} \mathrm{O}$ \\
\hline
\end{tabular}

Table 2 IR spectra of organic extracts.

\begin{tabular}{|c|c|c|}
\hline $\begin{array}{l}\text { Frequency. } \\
0.5\end{array}$ & $\frac{\mathrm{cm}^{-1}}{4^{2}}$ & Probable ass lgnment \\
\hline $3440(w) b)$ & & $\mathrm{OH}$ stretching \\
\hline $\begin{array}{l}2920(\mathrm{~s}) \\
2860(\mathrm{~s})\end{array}$ & $\left.\begin{array}{l}2920(s h) \\
2860(s)\end{array}\right\}$ & CH stretching (sym. and asym.) \\
\hline 1465 (ms) & 1465 (ms) & $\begin{cases}\mathrm{CH}_{3} & \text { sclssoring } \\
\mathrm{CH}_{3} & \text { degenerate bending }\end{cases}$ \\
\hline $1375(\mathbb{m})$ & $1375(\pi)$ & $\mathrm{CH}_{2}$ sym. bending \\
\hline $1035(\mathrm{vw})$ & $1035(\mathrm{~m})$ & \\
\hline 995 (Vw) & $995(m)$ & Ru-0 and/or Ru=0 stretching \\
\hline $960(\mathrm{vw})$ & $960(\mathbb{m})$ & \\
\hline $890(w)$ & $910($ w) & \\
\hline $860($ (w) & 860 (w) & $R u-0-R u$ stretching \\
\hline $755(w)$ & 755 ( & \\
\hline $720(\mathrm{~m})$ & $720(\mathbb{m})$ & $\mathrm{CH}_{2}$ rocklng \\
\hline $\left.\begin{array}{l}485(\mathrm{vw}) \\
465(\mathrm{vw})\end{array}\right\}$ & & $(\mathrm{Ru}-\mathrm{OH}) \mathrm{H}$ stretching \\
\hline $\begin{array}{l}380(\mathrm{vw}) \\
330-305(\mathrm{wb})\end{array}$ & $\left.\begin{array}{l}380(\mathrm{vw}) \\
310(\mathrm{wb})\end{array}\right\}$ & $\mathrm{Ru}-\mathrm{Cl}$ stretching \\
\hline
\end{tabular}

a) Initial aqueous hydrochrorlc acld concentration, mol $\mathrm{dm}^{-3}$

b) s=strong, ms=medlum strong, m=medlum, w=weak, vw=very weak, sh=shoulder, b=broad 
酸濃度で1.13-0.93の值であり, いずれも約 1 となった。このこと はルテニウム 1 原子に対してTOMACが 1 分子結合していること を示唆しており，この関係はルテニウムとTOMACの濃度の和を一 定に保ちながらそれらの濃度を変化させて, 一定盐酸濃度の溶液か ら抽出を行う連続変化法（Fig. 5) の結果からも支持された。す

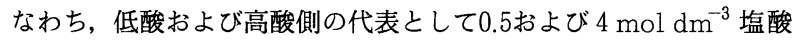
初濃度の所で調べた結果, いずれもモル分率, $[R u]_{\text {init }} /\left([R u]_{\text {init }}\right.$ $\left.+[\mathrm{TOMAC}]_{\text {init }}\right)=0.5$ で極大值をとり，ルテニウムと TOMACの モル比が $1: 1$ であることを示唆した。

さらに，一定のTOMAC濃度で水相を新しいものと取り換えなが ら繰り返し抽出を行い, 有機相中にルテニウムを飽和するまで負荷 させた溶液について，ルテニウムに対するアンモニウム基, 塩化物 イオンおよび水分子のモル比を化学分析により調べた結果をTable 1 に揭げた。その結果, 有機相中に形成される錯体の化学量論的組成 は, 後述の赤外吸収スペクトル測定より, 低酸および高酸側での抽 出錯体中にそれぞれ Ru-OHならびに $\mathrm{Ru}=\mathrm{O}$ 結合の存在が認めら れたので, 低酸側では $\mathrm{R}_{3} \mathrm{R}^{\prime} \mathrm{NRu}(\mathrm{OH})_{2} \mathrm{Cl}_{2} \cdot 2 \mathrm{H}_{2} \mathrm{O}$, 高酸側では $\mathrm{R}_{3} \mathrm{R}^{\prime} \mathrm{NRuOCl} \mathrm{Cl}_{2} \cdot \mathrm{H}_{2} \mathrm{O}$ のように表される。

\section{$3 \cdot 4$ 赤外吸収スペクトル}

ベンゼン希釈のTOMACにより0.5および $4 \mathrm{~mol} \mathrm{dm} \mathrm{dm}^{-3}$ 塩酸溶液 からルテニウムを抽出し，ルテニウムを飽和するまで負荷させた有 機相のベンゼンを減圧留去して単離した抽出物の赤外吸収スペクト ルを測定した。結果をFig. 6 および Table 2 に示す。

まずTOMACのアルキル基に起因する吸収に加えて，4 mol $\mathrm{dm}^{-3}$ 塩酸溶液 (高酸側) からの抽出物のスペクトルには, 1035, 995, $960 \mathrm{~cm}^{-1}$ にRu-OないしはRu=O伸縮振動吸収, そして 910 , $860,755 \mathrm{~cm}^{-1}$ にRu-O-Ru 伸縮振動吸収がそれぞれ分裂して現れ る。一方, $0.5 \mathrm{~mol} \mathrm{dm}^{-3}$ 塩酸溶液 (低酸側) からの抽出物のスペク トルでは, Ru-OないしはRu=O伸縮振動が1035, $995,960 \mathrm{~cm}^{-1}$ に
認められるが, これらの吸収帯強度は高酸側のスペクトルよりもか なり弱い。そして Ru-O-Ru 伸縮振動は890，860および 755 $\mathrm{cm}^{-1}$ に現れる。これに加えて, 高酸側の抽出物のスペクトルには 認められないOHおよび (Ru-OH)H伸縮振動の吸収が3440および 485 と $465 \mathrm{~cm}^{-1}$ にそれぞれ出現し, 低酸側の錯体が OH基を有するの に対し, 高酸側のそれは保持しないことを示唆している。

さらに，低および高酸からの両抽出物のスペクトルにはRu-Cl伸 縮振動 ${ }^{7)}$ に基づく幅広い吸収が 380 と $330-305$ および 380 と $310 \mathrm{~cm}^{-1}$ にそれぞれ認められ，いずれあクロロ錯体であることが明らかになっ た。

これらのことは先に述べた錯体の化学量論的組成を支持してい る。

$3 \cdot 5$ 希釈剂効果

各種の有機溶媒で希釈した $0.005 \mathrm{~mol} \mathrm{dm^{-3 }}$ TOMAC（ただし

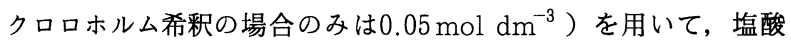
溶液からの $0.001 \mathrm{~mol} \mathrm{dm}^{-3}$ ルテニウムの抽出を行い, 抽出に及ぼ す希釈剤の効果について検討した。使用した希釈剤とそれらの各 種希釈剤パラメー夕 (比誘電率, 双極子モーメント ${ }^{8)}$, Shmidtな

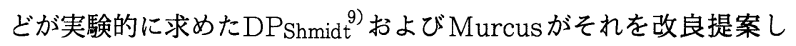
たDPMurcus ${ }^{10)}$ ) を分配比ととあにTable 3 に揭げた。さらに, 抽 出曲線はいずれの希釈剤であべンゼンのそれとほぼ類似の形状とな

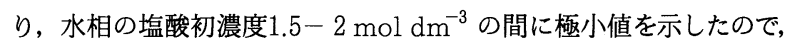
これらの代表としてクロロベンゼン, トルェン， 1，2-ジクロロ エタンおよびクロロホルム希釈の抽出曲線をFig. 7 に示した。

抽出効果は $0.5 \mathrm{~mol} \mathrm{dm}$ 塩酸 (低酸側) ではクロロベンゼン>oジクロロベンゼン>o-キシレン>p-キシレン>ベンゼン>トルェ

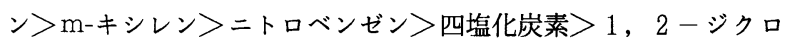
ロエタン> $2-$ ニトロプロパン>クロロホルムであり, $4 \mathrm{~mol}$ $\mathrm{dm}^{-3}$ 塩酸 (高酸側) ではO-ジクロロベンゼン》クロロベンゼン>

Table 3 Distribution ratio of ruthenium(III) from hydrochloric acid solutions with TOMAC in organic solvents used as diluents ${ }^{a)}$ and the diluent parameters.

\begin{tabular}{|c|c|c|c|c|c|c|c|c|}
\hline DUluent & Dlelectric & Dlpole mo- & DP & DP & & stribu & on rat & \\
\hline Dituent & constant, $\varepsilon$ & ment, Debye & $D P \sin ! d t$ & DPMarcus & 0.5 & & 2 & 4 c1 \\
\hline Benzene & $2.274^{25 d)}$ & 0 & 2.30 & 1.80 & 2.51 & 4. 20 & 3. 18 & 0.420 \\
\hline Chlorobenzene & $5.621^{28}$ & 1.782 & 2.4 & 2.68 & 5.55 & 20.0 & 37.8 & 5.28 \\
\hline o-dlchlorobenzene & 9. $93^{25}$ & 2.27 & 2.7 & 3.02 & 5.20 & 19. 8 & 50.0 & 19. 2 \\
\hline Toluene & $2.379^{25}$ & 0.375 & 1.80 & 1.55 & 2. 19 & 2.61 & 3. 43 & 0.621 \\
\hline $0-x y l e n e$ & $2.568^{20}$ & 0.44 & & & 3.89 & 4. 09 & 4. 83 & 1. 10 \\
\hline$m$-xylene & 2. $374^{20}$ & 0.34 & $1.8^{\circ)}$ & $1.33^{\circ)}$ & 2.01 & 2. 03 & 2. 44 & 0.276 \\
\hline$p$-xylene & 2. $270^{20}$ & 0 & & & 2. 94 & 3. 43 & 3. 94 & 0.882 \\
\hline Nitoro benzene & $35.742^{25}$ & 4.21 & 4.3 & 4. 30 & 0.525 & 1.02 & 3. 52 & 1. 61 \\
\hline Chloroform & 4. $806^{20}$ & 1.04 & 4.5 & 2.93 & 0.641 & 0.861 & 1.34 & 1.16 \\
\hline Carbon tetrachloride & 2. $228^{25}$ & 0 & - & - & 0.465 & 0.617 & 0.912 & 0.168 \\
\hline $1,2-d 1$ chloroethane & $10.335^{25}$ & 1.86 & 3.5 & 3.85 & 0.307 & 0.481 & 1.31 & 3.57 \\
\hline $2-n l$ toropropane & $25.52^{30}$ & - & 4.3 & 4.13 & 0.094 & 0.336 & 0.744 & 0.718 \\
\hline
\end{tabular}

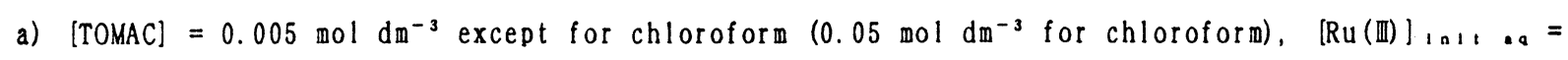
$0.001 \mathrm{~mol} \mathrm{\textrm {dm } ^ { - 3 }}$

b) Abbreviation for the emplrical dlluent parameter

c) Initial aqueous hydrochlorlc acid concentration, mol $\mathrm{dm}^{-3}$

d) Experimental temperature, $c$

e) Value as whole xylene 


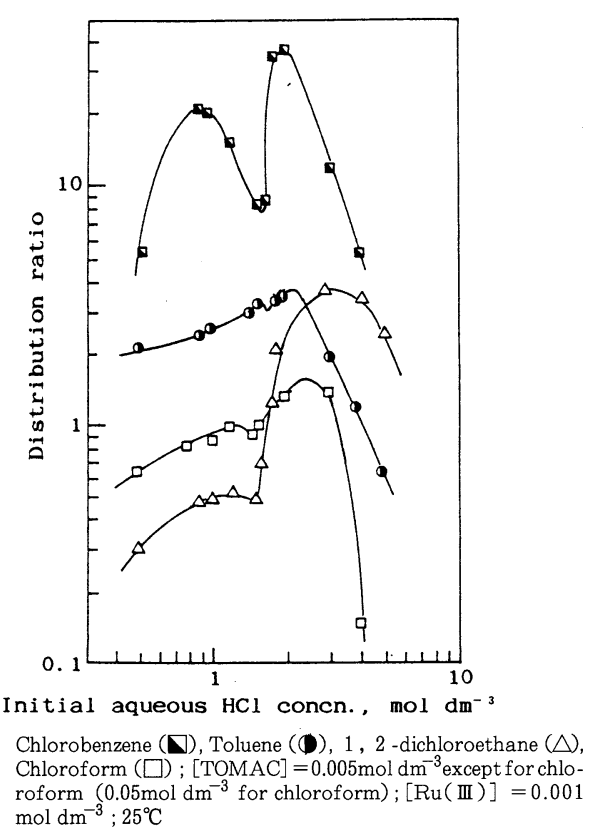

Fig. 7 Extraction isotherms of ruthenium( III) from hydrochloric acid solutions with TOMAC in

1,2 - ジクロロエタン>ニトロベンゼン>o-キシレン >p-キシレ ン> 2 -ニトロプロパン>トルエン >ベンゼン > m-キシレン>四 塩化炭素>クロロホルムの順となった。そして, クロロベンゼンお よび○-ジクロベンゼン希釈では低酸と高酸の領域がより明確となり, さらに, ニトロベンゼンおよび 1,2 - ジクロロエタン希釈では低 酸側に比べ高酸側の抽出効果が大きく促進された。

次に, 分配比とTable 3 に掲げた各希釈剤パラメータとの相関性 について検討した。ここで, クロロホルムは水素結合により抽出剤 と付加化合物を作り, 抽出効果を低下させることが一般に知られて いるので検討から除外した。その結果, DPShmidt およびDPMurcus 対 $0.5 \mathrm{~mol} \mathrm{dm}{ }^{-3}$ 塩酸初濃度における分配比の間で, それぞれ相関 係数 0.78 および 0.66 程度の相関性しか認められず, その他の組合せ については良好な関係は得られなかった。この原因として, Fig. 2 および 7 からもわかるように, 本抽出系では低酸側と高酸側の二 つの抽出曲線が大きく重なりあっているので, それらの抽出が互い に影響しあい相関性を悪くしていると推察される。

\section{$3 \cdot 6$ 抽出温度依存性}

抽出温度を $15-30^{\circ} \mathrm{C}$ まで変化させべンゼン希釈の $0.05 \mathrm{~mol} \mathrm{dm}^{-3}$

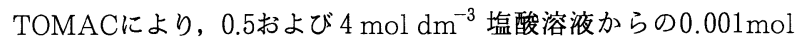
$\mathrm{dm}^{-3}$ ルテニゥムの抽出を行い, 抽出温度の分配比に及ぼす影響に つき検討した結果をFig. 8 に示す。

ルテニウムの分配比は塩酸濃度に関係なくいずれも抽出温度の上 昇に従って増加し, その温度依存性は $4 \mathrm{~mol} \mathrm{dm}^{-3}$ 塩酸よりあ 0.5

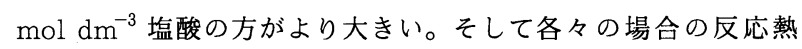
$\left(\Delta H, \mathrm{Kj} \mathrm{mol}^{-1}\right)$ が0.5および $4 \mathrm{~mol} \mathrm{dm}{ }^{-3}$ 塩酸についてそれぞれ 67.4，5.85 計算され，いずれも吸熱反応であることがわかった。

$$
\text { 4. 結 論 }
$$

ルテニゥムの抽出曲線は水相の塩酸初濃度 $1.5 \mathrm{~mol} \mathrm{dm^{-3 }}$ 付

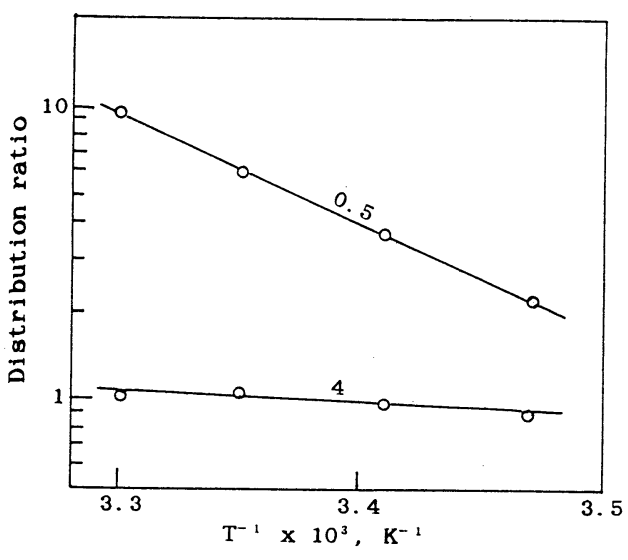

Numerals on curves are initial aqueous hydrochloric acid concentration, mol dm${ }^{-3}$; Benzene diluent; [TOMAC] $=0.005$ $\mathrm{mol} \mathrm{dm}{ }^{-3} ;[\mathrm{Ru}(\mathrm{III})]=0.001 \mathrm{~mol} \mathrm{dm}^{-3}$

Fig. 8 Temperature dependence on the distribution ratio.

近で極小となり, 低酸側と高酸側では抽出される化学種は異な ることが示唆された。そして低酸側ではプロトン, 高酸側では 塩化物イオンが関与し抽出を促進することがわかった。

有機相中に形成される錯体は, 低酸側では $\mathrm{R}_{3} \mathrm{R}^{\prime} \mathrm{NRu}(\mathrm{OH})_{2}$ $\mathrm{Cl}_{2} \bullet 2 \mathrm{H}_{2} \mathrm{O}$, 高酸側では $\mathrm{R}_{3} \mathrm{R}^{\prime} \mathrm{NRuOCl}_{2} ・ \mathrm{H}_{2} \mathrm{O}$ の化学量論的組成 であった。

これらの結果は抽出物の赤外吸収スペクトルの測定によって あ支持された。

希釈剤の違いによる抽出曲線の形状はいずれも類似であり， 抽出は低酸側ではクロロベンゼン, 高酸側ではO-ジクロロベン ゼンであっとあ効果的であった。

ルテニウムの分配比は抽出温度の上昇に伴い増加し, その依 存性は低酸側でより大きいことが判明した。

終わりに, 三塩化ルテニウムを提供して戴いたエヌ・イーケ ムキャット(保ならびに抽出剤のTOMACを提供して戴いた広栄 化学(森に対し感謝する。

\section{引用文献}

1 ) Cleare, M. J., Charlesworth, P. and Bryson, D. J. : J. Chem. Tech. Biotechnol,, Vol. 29, p. 210, (1979) ; Al-Baxzi, S. J., Chow, A., Talanta, Vol. 31, p. 815, (1984)

2 ) Taqui Khan, M. M., Ramachandraiah, G. and Shukla, R. S.: Inorg. Chem., Vol. 27, p. 3274, (1988)

3) Morris, D. F. C. : Sep. Sci., Vol. 2 , p.635, (1967) ; Epperson, C. E., Landolt, R. R. and Kessler, W. V. : Anal. Chem., Vol. 48, p. 979, (1976) ; Chiu, J., Landolt, R. R. and Kessler, W. V. : ibid., Vol. 50, p.670, (1978) ; Payne, S. T. : Analyst, V ol. 85, p. 698, (1978)

4) Watanabe, H., Utsuyama, H. and Sahara, S. : Chem. Lett., p. 1391, (1990)

5) Sato, T., Nakamura, T. and Kuwahara, M. : Solvent Extr. Ion Exch., Vol. 3 , p. 283, (1985)

6) Horwitz, E. P., Martin, K. A. and Diamond, H. : Solvent Extr. Ion Exch., Vol. 6, p. 859, (1988)

7 Sarma, V. C., Sarma, K. P. and Podder, R. K. : Poryhedron, Vol. 7 , p. 1727 , (1988)

8）日本化学会編：改訂 3 版 化学便覽，基礎編 II, p. 502, p. 720, (1984), 丸善, （東京）；浅原照三，他編：溶剂ハンドブック，p. 177 (1976)，講談社, “(東京)

9) Shmidt, V. S., Mezhov, E. A. and Novikova, S. S. : Radio-khimiya, Vol. 9, p. 700 , (1967)

10) Marcus, Y.: Solvent Extr. Ion Exch., Vol. 7, p. 567, (1989) 